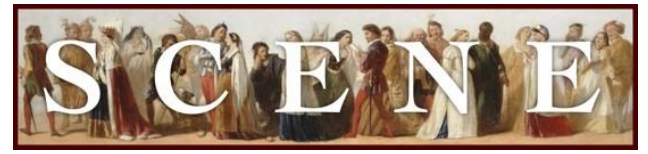

\title{
Editorial: Is there a (North-)West Coast Shakespeare?
}

IS THERE A (NORTH-)WEST COAST SHAKESPEARE? ISSUE 2 PONDERS THIS QUESTION WITH reviews of plays primarily staged in Vancouver, Seattle, and the Fraser Valley - lands known variously as the Pacific Northwest, southwestern British Columbia, and unceded Coast Salish territories. Today, people from all over the world reside in and visit these lands. In a region that has been described as "@ the edge" (theme of the Congress 2013 of the Humanities and Social Sciences, hosted by the University of Victoria, BC.), in various ways these meetings have the potential to create new "edges" and to reframe definitions of center and margin.

For Vancouver residents, Shakespeare is associated principally with Bard on the Beach, a festival company offering four plays in repertory every summer. Taken in recent years to staging at least one crowd-pleasing comedy with lively, nostalgic music, Bard on the Beach's Shakespeare (and Shakespeare-associated) productions become occasions to revel in music that recalls the recent past, that might remind audience members of movies they had seen as children.

The Bard on the Beach festival takes place in Vancouver's Vanier Park on the site of Sen'ákw village, in territory shared by the Squamish, Musqueam, and Tsleil-Waututh Nations (https://bardonthebeach.org/history-of-vanier-park/). Those of us present at The Winter's Tale's opening night in 2017 were generously welcomed by a Councillor of the Squamish nation, who drew a connection between that play's concern for the abuse of women and a broader need to address violence against and silencing of women in Canadian culture. She invited the audience to sing the Women's Warrior Song, a politically significant call to action which draws attention to Canada's missing and murdered Indigenous women. The audience seemed keen to participate, but unfortunately few seemed to know the song. Bard's Winter's Tale did highlight women's voices by having the character Paulina speak a prologue and speak the words of Time.

Bard's Much Ado layered over the play a 1950s, Felliniesque world of Italian movie stars, including Vespas on stage and "toe-tapping" music (Preus). Bard's recent Merry Wives leveraged iconic 1960 s tunes like "These Boots were Made for Walking" and "Stand by your man" to celebrate the world of a small-town Windsor, Ontario. The nostalgia for small-town community 
and the aesthetics of moose heads and curling banners played well to this Vancouver audience, whether they personally identified with this history or were learning about it from the show.

Recently a non-Shakespearean play has been included among Bard on the Beach's repertory of four plays - generally of contemporary Canadian significance. For its 2017 season, Bard on the Beach presented Shylock (1996) by Mark Leiren-Young as a companion to its staging of The Merchant ofVenice. If Bard's Merchant focused its audience's attention on the "moral ugliness" of both Antonio's Venice and aspects of "our own cultural moment" (Kelly), giving new meaning to Portia's line, "nothing is good, I see, without respect" (Arab), then the company's nonShakespearean offering, Shylock, added its own perspective on art's ethical role.

Of the four 2017 Bard productions, three (including Shylock) were explicitly engaging with 21st century politics of gender and race. Two Gentlemen of Verona made sense of the ending by having Julia and Silvia join the forest outlaws - all women, in this version. In this way, Bard's Two Gentlemen managed to keep a light tone through most of the play, while still making emotional sense to a twenty-first century audience. Bard's Winter's Tale also pushed the "edge" with a mise en scène that combined Greek masks and choral dancing with futuristic/cubist animal puppets in Bohemia, a meditation on art and nature for the animated age. (The Winter's Tale also played nearby in Seattle, where the focus on rebirth via art was supplemented by the poetry of Pablo Neruda.) Issue 2 of Scene offers two reviews of each of the Bard productions, reflecting its centrality in the Vancouver Shakespeare scene and showing some of the diversity of response to these productions.

Shakespeare lovers in Vancouver also could see Piya Behrupiya, a Hindi translation of Twelfth Night by The Company (Mumbai), presented with song and in nautanki folk-theatre style. Originally commissioned for the London Globe-to-Globe festival, Piya Behrupiya was localized with reference to Vancouver's Lions Gate Bridge. Also available in the region were Troilus and Cressida, a strong student production presented by Vancouver's Studio 58, which connected the Trojan war with contemporary news, a Taming of the Shrew set on a golf course in the Fraser Valley, and Verdi's Otello, programmed in the Vancouver Opera season alongside Dead Man Walking and The Marriage of Figaro, which used projections (including a of raging sea) and a simple set to echo the opera's emotional storminess.

Other Shakespeare-related fare (not reviewed here) included The Society of the Destitute Presents Titus Bouffonius, "a vulgar clown retelling of Shakespeare's bloodiest tragedy," which played at the Cultch in East Vancouver; "a free adaptation of Verdi's opera [Macbeth] - and by free, we mean daring, radical and uninhibited in its transformations" by the South African theatre company, Third World Bunfight, set in the Democratic Republic of Congo; and Shakespeare's 
Sister, a musical about Judith Shakespeare and an imagined community of seventeenth-century women, which played at the Firehall Arts Center on the downtown eastside, an area currently hard hit by the opioid epidemic.

-- Kevin Quarmby, Editor, and Melissa Walter, Associate Editor 